\title{
Modernization of Education in Egypt: The Liberal Movement Towards Dewey's Ideas
}

\author{
AbdelHady M. ElNagar (Al-Azhar University, Egypt) \\ Eva Krugly-Smolska (Queen's University)
}

\begin{abstract}
This paper traces, from a historical perspective, the acceptance of the educational ideas of John Dewey (1859-1952) in Egypt in context of its earlier and ongoing efforts to modernize the education system. It first discusses the different political, educational, and social factors that might have facilitated the acceptance of Dewey's educational ideas in Egypt. Then it discusses the ways through which Dewey's educational ideas reached into Egypt, including establishment of European and American schools in Egypt, sending educational missions to Europe and the USA, and translation of works of western intellectuals into Arabic. It also discusses the adoption of Dewey's ideas by many Egyptian educationists. The study focuses on Al-Qabbani (1898-1963), the progressive thinker and Minister of Education in Egypt, and shows the extent to which his educational ideas agreed with Dewey's educational philosophy. Finally, the study explores the application of some of Dewey's progressive educational ideas in Egypt.
\end{abstract}

\begin{abstract}
Résumé
Cet article retrace, de par le biais d'une analyse historique, l'acceptation des idées éducatives de John Dewey (1859-1952) en Égypte dans le but de moderniser l'intégralité du système éducatif du pays. Il discute tout d'abord les différents facteurs politiques, éducatifs et sociaux qui peuvent avoir facilités l'acceptation de ces idées éducatives en Égypte. Il se concentre ensuite sur les différents chemins au travers desquels les idées de Dewey se sont insérées dans le contexte égyptien, tel que la création d'écoles européennes et américaines, l'envoi de missions éducatives en Europe et aux ÉtatsUnis et la traduction d'écrits d'auteurs occidentaux en langue arabe. L'article discute également de l'adoption des idées de Dewey de la part de beaucoup d'éducateurs égyptiens. Il se concentre surtout sur l'intellectuel progressiste et Ministre d'Éducation Égyptien Al-Qabbani (1898-1963) et montre ses liens étroits avec la philosophie éducative de Dewey. En conclusion, cet écrit explore la mise en pratique de quelques unes des idées éducatives progressistes de Dewey dans le contexte égyptien.
\end{abstract}

\section{INTRODUCTION}

Modernization is a key word used to describe the application of new scientific theories and technologies, especially as practised in the developed West. It is also used in connection with government administration, the legal system, the economy, and education (Hyde, 1978).

From a historical perspective, there was a direct connection between Western ideas and the modernization movement of education in Egypt. The beginning of modernizing Egyptian education dates back to the time of the French occupation in 1798-1799, a period that stimulated Egyptian thought and provided its leaders with the opportunity to compare and contrast the two different cultures. Thus, the Egyptian culture was subjected to a severe test (Faksh, 1980). This event was a turning point in the history of modern Egypt, since it suddenly brought the 
Egyptians into contact with western culture and its accompanying elite of France's scholars and experts (Dune, 1968).

In response, Egyptian leaders initiated a series of changes to modify elements of Egypt's traditional culture. The most important social change brought about was the development of the modern civic education system, introduced by Mohammed Ali who ruled Egypt from 1805 to 1849. It was a system that was vastly different from the existing religious education taking place in Al-Azhar institutions. The result of this educational innovation was the creation of an educational system competing with the traditional one but not supplanting it. While the modern schools provided a civic European-style of education (Faksh, 1980), the new system lacked firm roots among the public, especially the Egyptian farmers. It also failed to develop a general education system that could form the basis of specialist teacher training, which later compelled Mohammed Ali to rely on outside assistance, particularly from France (Williamson, 1987).

The movement of modernizing education in Egypt continued during the regime of Ismail (1863-1879), aided by educationists and organizers such as Dor bey, Rogers bey, Cherif pasha, and Ali Mubarak pasha. Dor bey, a Swiss citizen with an extensive educational experience, was one of the ablest officers in the Egyptian civil service and did much to improve schools in Egypt. Rogers, ruler Ismail's agent in London, was appointed as an educational inspector (Rifaat, 1947). The primary concern of the first Egyptian intellectuals during this period was to acquire European methods of education. For them this was essential to the emergence of a modern state in Egypt. They were also concerned with exploring the modern methods of educational administration that could support the successful adoption and adaptation of such methods and techniques (Vatikiotis, 1985).

In 1882, Britain occupied Egypt for both financial and strategic reasons, gaining a decisive voice in all areas of Egyptian life, including education, health, and the military. Under the occupation expansion in these fields lagged as the population grew (Botman, 1991). There were some patriotic efforts to develop the educational system at that time but, unfortunately, all of these reforms had limited consequences for the educational process, which remained highly scholastic, authoritarian, and rigid. Both the primary and secondary schools shared many of these deficiencies (Szyliowicz, 1973). The governmental education systems as well as the foreign ones were elitist in the sense that they continued to provide education to children of the middle and upper classes. Consequently, the gap separating the educated young Egyptian from the illiterate majority of the population grew wider. The modernized sensibilities of the 
educated people differentiated them from the general population that stood as staunch supporters of traditionalism and conservatism (Faksh, 1980).

A continuous search for new and appropriate educational ideas to address these deficiencies was required. There were two dominant responses to these educational problems, the liberal trend and the conservative one. Both called for educational modernization but through different paths. On the one hand, by the 1920s the desire of Egypt to become a modern society had been widely accepted by many of the country's liberal politicians and intellectuals. Modernization meant 'westernization' and was construed as the adoption of European material culture; including its technology, economic institutions, and political structures. It also implied the absorption of the intellectual aspects of western civilization and the mentality of the west (Gershoni \& Tankowki, 1995). On the other hand, the conditions of the 1930s and 1940s created a suitable environment for the growth of conservative sentiments and concepts that lay at the centre of Egyptian thought. It occurred at many levels, including the emergence of new intellectual production concerned with the civilization and values of Islam as criteria for modernizing Egypt (Gershoni \& Tankowki, 1995).

It is worth mentioning that there was no inevitable conflict between the two trends, both influenced each other. According to Hyde (1978), the notable impression is that innovation for Egypt was equally as important as conservation, especially in cultural issues. This is not merely a nationalistic sentiment, but a sincere belief that Egypt had something worth preserving. Historically, Egypt also had been open in general to the world around it, receptive to all that is new, remodelling, reshaping it, and adding to it its own Egyptian character.

This paper argues that the acceptance of John Dewey's educational ideas in Egypt was influenced by both the growing liberal intellectual trends and the domestic educational problems noted above. Located within the context of the historical development of the modernization of education movement in Egypt, this study discusses the different political, educational, and social factors that may be seen to have facilitated the acceptance of Dewey's educational ideas in Egypt. It then traces the different, and overlapped, stages of accepting Dewey's educational ideas including the reach, adoption, and the application of these ideas in practice.

\section{WHY THE ACCEPTANCE OF DEWEY'S IDEAS IN EGYPT}

The answer to this question may be divided into two parts, the first concerns Dewey's ideas themselves, and how expressive they are about the pupils and their aspirations, regardless of their place, religion, or race. The second is about the internal political, educational and social circumstances in Egypt, especially 
during the first half of the twentieth century. These circumstances might be seen to have facilitated the acceptance of Dewey's ideas in Egypt as follows:

\section{From the political side}

The pattern of the political system in Egypt during the British occupation was basically triangular - consisting of the British, the King, and the Wafd party. However, it could be argued that there were only two main forces: the British and the Wafd as the embodiment of the national movement. The king had not yet emerged as a significant political power (Deeb, 1979). The British formally stood outside the local political arena, but in practice often intervened in domestic Egyptian politics by supporting particular politicians and parties, and by proffering 'advice' to the ministers, and twice by issuing the final determination of the Egyptian government's composition (Jankowski, 2002).

Under the British occupation, the government controlled both the press and education and aimed to spread a negative image of the national movement's leaders in the press and educational textbooks as a military mutiny and unlawful rebellions against the legitimate authority (Mayer, 1988). The British occupation facilitated the contact between Egypt and western culture. The general political and cultural atmosphere was heavily westernized; this was certainly the case with the state-controlled school system in which the bulk of educated younger Egyptians were being socialized. The emphasis of the curriculum in the state schools was on non-traditional, western-derived, or modern, subject matters. In the1930s, for example, the first three years of study in secondary schools devoted only 20 of 105 class hours to the study of Arabic culture, and the other 85 hours were allotted to the study of foreign languages, the natural and social sciences, and physical education (Gershoni \& Jankowski, 1995).

\section{From the educational side}

There was an active movement for the scientific preparation of teachers. AlQabbani was entrusted with the deanship of the Teachers' Institute - the first institute established in 1929 in Cairo for the preparation of primary and secondary school teachers. The institute under his leadership was reputed to be a progressive centre for educational research and professional in-service training of teachers (El-Shibiny, 2007). Also Al-Qabbani founded a number of educational associations in Egypt and directed them towards technical and educational objectives and towards improving education according to modern concepts and methods. One of these societies the Association of Modern Education, was established in 1935 as an Egyptian branch of its headquarters in London. This 
association became a pioneer in the pragmatic movement in Egypt and the Arab world (Kombar, 2000).

\section{From the social side}

The idea of modernization in general received great support from notable Egyptian thinkers and socialist reformers such as Mohammed Abduh (18491905) and Rashid Reda (1865-1935). These modernists believed in revitalizing the community in response to the new conditions in the world. They were confident that the strength and flexibility of religion would allow the modernizing of society. These reformers responded to the liberal ideas in different ways. Mohammed Abduh, for instance, supported educational and legal reform, the emancipation of women, economic development, and governmental organization (Botman, 1991). Abduh thought that society could be strengthened only if it accepted the need for change in the context of its basic principles that should be the moral basis of a modern and progressive society. This moderate trend of reformation had a deep appeal in Egypt especially among those who wanted to modernize the society without abandoning its original and cultural bases (Hopwood, 1982).

\section{THE REACH OF DEWEY'S IDEAS INTO EGYPT}

The first stage in our analysis of the acceptance of Dewey's educational ideas in Egypt is the reach of these ideas into Egypt. This stage extended basically during the first half of the twentieth century. At that time there were many ways through which the ideas of Dewey reached Egypt, and consequently the Arabic world, without Dewey visiting the region. These are addressed below.

\section{European and American schools in Egypt}

The first private school set up in Egypt in the nineteenth century was an American school attached to the Orthodox Church at Bulak. It was an elementary school and undoubtedly due to the influential position of the American community at court, it was encouraged to give some attention to the education of its children (Dunne, 1968). Later, Ismail's patronage of education extended to European missionary schools in Egypt. His donations of land and money to missions helped to establish efficient schools for the European communities in Egypt and also for the Egyptians themselves (Rifaat, 1947).

The establishment of these schools increased under the British occupation (1882-1952). Teaching was of a higher level than that in local schools, and the curriculum encouraged the adoption of progressive western ideas. Foreign language institutions provided students with more than a mere facility with 
western languages. They also conveyed, through both classroom experience and social interaction, modern notions of class, nation, arts, and politics distilled from European and American history. Thus they contributed to the development of an international worldview and to the encouragement of social criticism and political awareness (Botman, 1991). Most of these issues were the focus of Dewey's basic writings.

It is worth mentioning that the American University in Cairo (AUC) is an important educational organization that also applied and taught the American education style. It was established in 1919 and its aims were to create an English language medium university to contribute to the intellectual development of the people in Egypt and the Middle East (Beattie, 2005). The School of Humanities and Social Science offered academic programs in the fields of American studies, philosophy, and history (Ministry of Higher Education, 2002).

\section{Educational missions to Europe and the USA}

At an early time Egypt had made its decision to adopt different methods of organization, which is demonstrated by the missions of young Egyptian scholars to Europe. Egypt sent them to see for themselves what was lacking in their country, what the westerners had to give and teach, and what was suitable to the ideas of progress and reform (Dunne, 1968). Their major subjects for study in Europe and the USA included diverse fields such as medicine, pharmacy, engineering, and education. The university students sent abroad later replaced European officials in schools and governmental departments (Moehlman, 1963).

In the field of education, those missions more recently included researchers and in-service teachers; the Ministry of Higher Education sent them abroad to study in many academic and educational fields. Educational missions were sent to the most famous universities in the United States, the United Kingdom, and France. Many programmes were carried out to raise the professional standard of teachers by studying developed educational theories and technologies of education (Ministry of Education, 1997). These programmes have been developed for the trainees with special emphasis on the use of new computerbased technologies, and exposure to the new educational strategies and activities in these countries (Ministry of Education, 1998).

\section{Translation Activity}

Since most of this modern, Western, knowledge was available only in European languages, English, French and Italian, it was a crucial challenge for Egyptians to acquire it and to translate it into Arabic. Egyptians who had studied in Europe as members of the state's educational missions, or who had studied in the famous 
school of languages in Cairo, undertook the translation of basic works in the various sciences from leading European languages (Vatikiotis, 1985).

As a result of this continuous translation activity in Egypt, there was a great deal of scientific literature that was translated into Arabic in all fields including education. Many books and papers by Dewey were translated and published in Arabic, including his books Democracy and Education, and Experience and Education. It is worth mentioning that the translation of these books, and others, contributed to forming what Dewey defined as a philosophy of education or a general theory of education in Egypt, that subsequently influenced the formation of educational policies and many of educational policy makers, such as AlQabbni, as the study shows.

The cover of the Arabic version of Dewey's book Democracy and Education. The translators are Dr. Mona Akrawy and Mr. Zakaria Mikhail. The book had been translated and published for the first time in 1950, and for the second time through the Egyptian Commission of Authorship, Translation and Publishing in 1954.

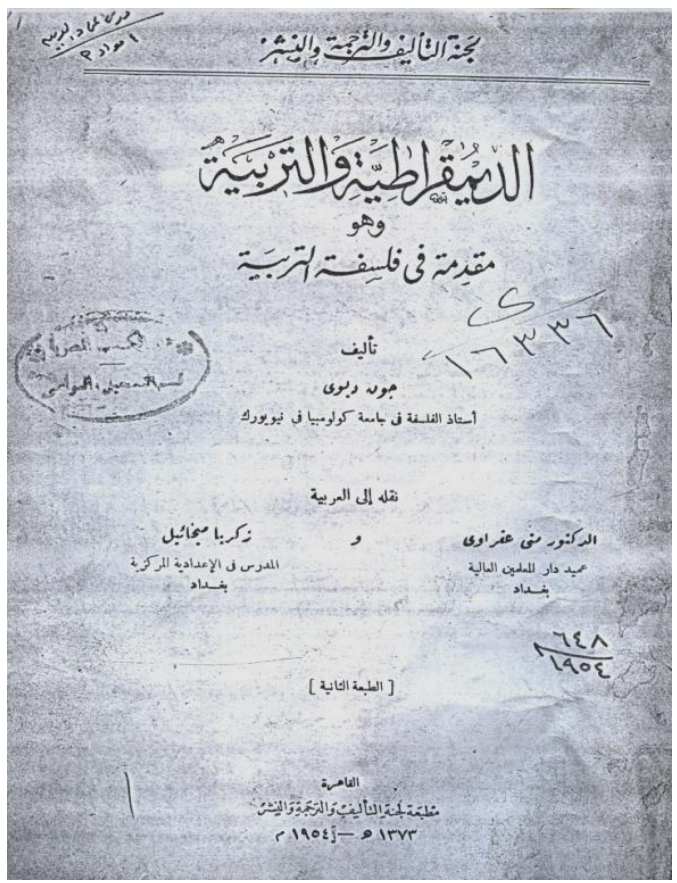


The cover of the Arabic version of Dewey's book Experience and Education. The translators are Dr. Mohammed Ramadan and Naguib Eskander, the revisionist Dr. Mohammed Badran. The book was published through the Ministry of Education in Egypt; the publisher was Al-Anglo Library in 1976.

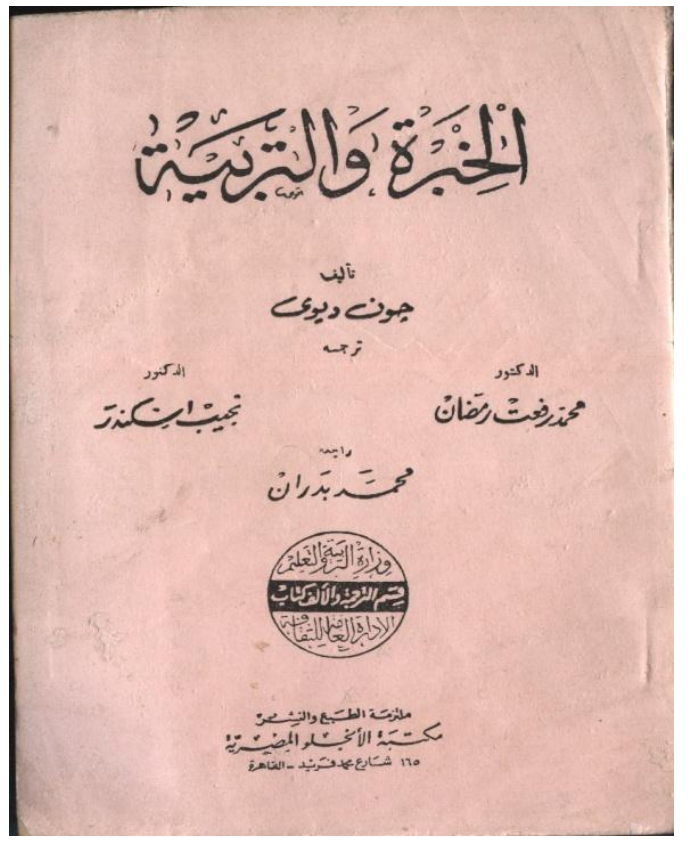

\section{THE ADOPTION OF DEWEY'S IDEAS}

After establishing the modern Egyptian university of Cairo in 1908, there was an emphasis on westernizing education. This emphasis was most pronounced at the university level with its European academic structure, largely European teaching staff, and with western subject matters usually presented in European languages. The natural result of both the structure and the content was to produce many Egyptian graduates who simply adopted western ideas (Gershoni \& Jankowski, 1995). Many Egyptian thinkers were influenced by the progressive ideas of European and American thinkers like Dewey and others. The general educational orientation, which was reinforced by many of those intellectuals especially in the 1930's and 1940's, like Lutfi Al-Sayd, Taha Hussain, and Isma'il Al-Qabbani, was a western one with strong liberal elements as part of it (Williamson, 1987).

Education, according to Ahmed Lutfi (1872-1963), should aim first to foster the independence of the individual as a personality trait, and second, to imbue a desire for responsible participation by individuals in community life. These traits are essential because the strength of a nation lies in its character. The cultivation of the mind and the refinement of feelings, in addition to social, economic, and political reform depend upon the education and upbringing of individual citizens. The reform of society must begin with reform of the national character. For Lutfi 
the remedy of the society's ills lay in the gradual transformation of the Egyptian character through education, not political revolution (Vatikiotis, 1985). He associated education with what he called the 'end of ends' or the independence of Egypt. To him education was in fact the only road to independence (Ahmed, 1968). The positivist and utilitarian conception of nationalism led Lutfi to argue for a more pragmatic system of education, which prepares the individual to lead a more active life in the community. It also led him to prefer an ethical and moral training for students based on the humanistic values of modern European philosophy. He was interested in discussing the modern conditions under which civilized society would flourish (Vatikiotis, 1985).

Taha Hussain's (1889-1973) concern for the values of western scholarship and pragmatic education are known. He saw Egypt's civilization as it drew on the classical civilizations of Greece and Rome, and he was a severe critic of traditional education in Egypt. Husain became, in the early 1950s, Egypt's Minister of Education. In his famous book The Future of Culture in Egypt, Hussain set out his views on education. He stressed the importance of education for democracy and the personal development of individuals' capabilities (Williamson, 1987). With Hussein a new call for education as a right for all Egyptians was made, and was equated with the right of free water and air for all Egyptians (BahaEldin, 1997).

Al-Qabbani (1898-1963) was the first Egyptian educational pioneer whose academic formation in the field of education included both theory and practice. He became well known as an educational innovator in his ideas and practices, especially after his return from a one-year scholarship in London in 1917-1918. Al-Qabbani was able to study for himself Dewey's work, which was enjoying great popularity at the time. He was a skilful and inspired strategist who was able to adapt progressive ideas to the Egyptian and Arab milieu, and who applied them with great success. The high-ranking official posts that he held assisted him in his efforts (Kombar, 2000).

\section{Al-Qabbani and Dewey: A Comparative Perspective}

It is well known that Al-Qabbani was among the Egyptian educationists who actively adopted Dewey's ideas in the field of education. By reading his famous book Studies in Education's Issues or Drassat Fe Masael Al-taliem, published in 1951, it seems that Al-Qabbani drew substantially upon the writings of Dewey and other pragmatists like James and Kilpatrick. 
Page 60 of Al-Qabbani's book Studies in Education's Issues. The page shows that Al-Qabbani relied on many of Dewey's writings to support his positions in education. These writings include a paper by Dewey about The Child and the Curriculum and his book Democracy and Education.

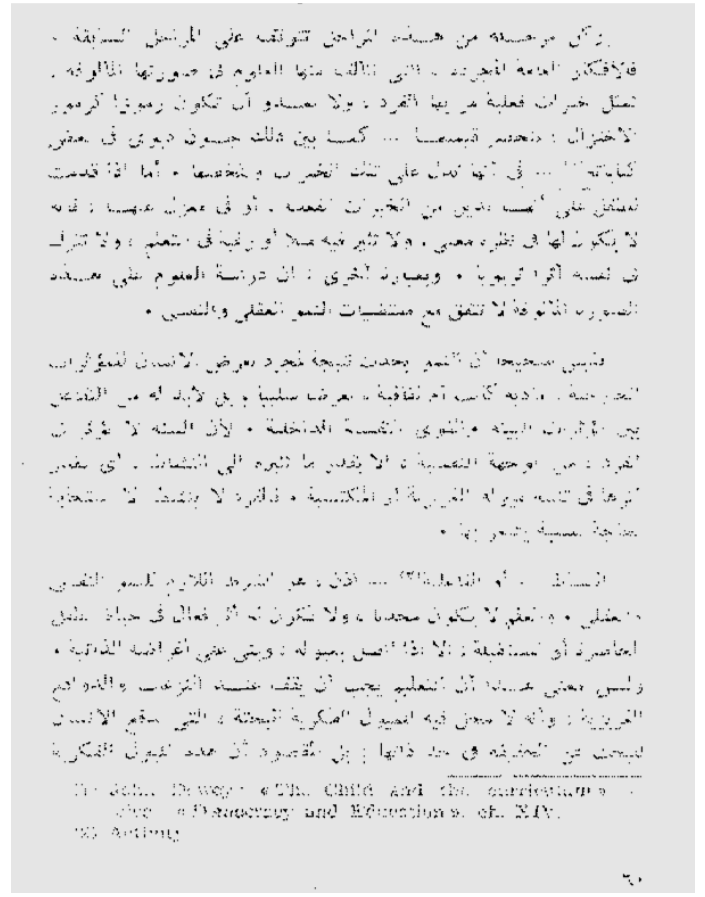

But the emerging question is; to what extent did Al-Qabbani agree with Dewey's progressive ideas in the education field? To answer this question we will present Al-Qabbani's and Dewey's positions in some educational issues to explore the extent of agreement between them concerning these issues. Some consider that the central concepts in Dewey's educational theory are: the aim of the activity or education, the agent responsible for the activity or the teacher, the subject of the activity or the pupil, and the means by which the aim is achieved or the curriculum and method (Archambault, 1964). The study will explore the extent of agreement between Al-Qabbani's position and Dewey's position in these four central concepts.

\section{Aims of Education}

It is well known that Dewey criticized traditional education in the USA and called for a new or progressive education. He believed the fundamental difficulty with the traditional means of instruction was their psychological base. This orientation, he argued, considered the child a passive receptor of external information; his or her will a force to be controlled, and his or her desire to be mischievous and immature. Addressing this misconception created the need for a 
totally new manner of education, which in turn necessitated a re-definition of the educational aims, the role of the teacher and the pupil, and the subject matter (Archambault, 1964). For Dewey, according to this new or progressive manner of education, schools:

Exhibit, as compared with traditional schools, a common emphasis upon respect for individuality and for increased freedom; a common disposition to build upon the nature and experience of the boys and girls that come to them.... They all display a certain atmosphere of informality, because experience has proved that formalization is hostile to genuine mental activity and to sincere emotional expression and growth. Emphasis upon activity as distinct from passivity is one of the common factors. (Dewey, 1964, p. 170).

Thus Dewey pays most attention to child development. For him "the child is the starting point, the centre, and the end. His or her development, his growth, is the ideal. It alone furnishes the standard. To the growth of [the] child all studies are subservient; they are instruments valued as they serve the needs of growth" (Dewey, 1964, p. 343). So "the primary aim of school education should be to ensure the continuance of education by organizing the powers that ensure growth" (Skilbeck, 1970, p. 18).

Al-Qabbani also criticized traditional education from a psychological point of view and argued the need for a modern education. According to him, with the aspiration of the nation to generalize public access to education, it became apparent that traditional education was not appropriate for the majority of the children, because it did not prepare them for the practical life to which they would graduate. Since pupils' tendencies and their mental capabilities do not necessarily like purely theoretical studies, the need was for a new democratic philosophy of education that harmonized links between knowledge and work, and between culture and practical life (Al-Qabbani, 1951). In context of this new philosophy Al-Qabbani believed that:

The school must pay a special attention to teaching morals for the pupils and to strengthening their personalities.... We realize the necessity of organizing the pupil's social relationships, also his or her work outside the school classroom, either in the playground, restaurant, or in the house. The goal of this organization is to educate his or her sentiment and will... it could be achieved through educating the organized liberty and the common sense. (Al-Qabbani, 1951, p. 23)

It seems that both Dewey and Al-Qabbani called for a new type of education that satisfied the pupils' tendencies and mental capabilities and respected their freedom and individuality. Both also agreed that this new education is the basic 
medium to promote well-being of society, especially in the political and democratic fields. For Dewey, on one hand, education and society are dynamically interactive and inter-dependent. Therefore if human beings hope to develop and maintain a particular type of society or social order, they must develop and maintain the particular type of education system conducive to it (Benson et al, 2007). For example, to preserve the American democratic experiment, in order to survive, American democracy, Dewey maintained, must be transformed by a revolution in education, followed by a social and economic revolution. One cannot occur without the other, but education must first be revolutionized because it is the process through which the needed societal transformation may be accomplished (Edmondson, 2006).

For Al-Qabbani, similarly, education should assist individuals and prepare them for the desired change. He believed that:

The final aim of education is upgrading the people to the highest standard of living and preparing the individual to undertake his role in the national renaissance. If this renaissance requires the development of a patriotic sense in the pupils and the feeling of national dignity, so education has to achieve this. And if this renaissance requires the establishment of democratic and representative systems in the state, so education has to prepare individuals to understand their rights and duties in the political and social life, enlighten their minds, and polish their thinking. (Al-Qabbani, 1951, p. 143)

\section{The Teacher}

According to Dewey the teacher must be well prepared especially in the area of educational psychology. For him "since education is a rational process in harmony with the laws of physical development, it is plain that the educator need not and should not depend upon vague inductions from a practice not grounded upon principles. Psychology cannot dispense with experience, nor can experience, if it is to be rational, dispense with psychology" (Dewey, 1964, p. 195). Thus a teacher's preparation should start with the child's existing experience, with a theory of the impulsive tendencies of the child, and with understanding the conditions of growth including a genetic study of the child's history, his socio-cultural context (Skilbeck, 1970).

In that context, Al-Qabbani agreed with Dewey also on the importance of scientific and psychological preparation for the teacher. For him "the deep study of our education problems leads us to be more content that the teacher is the cornerstone of reforming it.... they, in the final estimation, are responsible for achieving our definite goals of education" (Al-Qabbani, 1951, p. 179). So he 
believed that "for the school to develop the pupil's mind and to widen his or her tendencies and mental faculties, we must start with the teacher's mind and his or her tendencies and mental faculties; teacher education must be higher ranking than it is" (Al-Qabbani, 1951, p. 140).

\section{The Pupil}

According to Dewey, the pupil should be looked upon as wilful, purposeful, curious, and active. And the teacher should be considered a guide who should help the pupil to achieve his or her own purposes (Archambult, 1964). For him "the positive principle is maintained when the young begin with active occupation having a social origin and use, and proceed to a scientific insight in the materials and laws involved, through assimilating into their more direct experience, the ideas and facts communicated by others who have had a large experience" (Dewey, 1961, p. 193). Thus "the child is expected to 'develop' this or that fact or truth out of his own mind. He is told to think things out, or work things out for himself, without being supplied with any attendant conditions, which are requisite to start and guide thought. Nothing can be developed from nothing" (Dewey, 1964, p. 349).

Al-Qabbani's position concerning the pupil's role in the learning process is almost the same. For him:

The pupil should be active not just receptive, he or she doesn't acquire scientific facts because he or she should learn it, but because his or her feeling that he or she needs to learn it. So he or she asks to learn it himself. A pupil learns facts to reach his or her own goals; thus it becomes a part of his or her experiences and thinking structure. The pupil mustn't easily receive already prepared facts in the school, but he or she should be left in front of the real problems face to face, and encouraged to search for suitable solutions. (Al-Qabbani, 1951, p. 14)

\section{Curriculum and Teaching Method}

In his theory of the curriculum, Dewey tried to bring together the various elements, which he regarded as relevant and important. They include the interests and learning capacities of the child, different types of subject matter, the social context, and democratic values. Dewey didn't accept the curriculum as being fully prepared kits of materials, schemes of work, and syllabuses (Skilbeck, 1970). He adopted the 'Child-Centred Curriculum' since in his view the curriculum had to be centred on the child. Thus the child's learning environment is in reality a grand manipulation on the part of his teacher (Edmondson, 2006). $\mathrm{He}$ also recommended the 'conjoint activities' that allow children to assist in 
organizing their own education. If children could express themselves articulately and sincerely, they would tell a different tale by which they would craft a more worthwhile curriculum for themselves (Edmondson, 2006). For Dewey there is a unity between subject matter and method. He believed that "method is a statement of the way the subject matter of an experience develops most effectively and fruitfully. It is derived, accordingly, from observation of the course of the experience where there is no conscious distinction of personal attitude and manner from material dealt with" (Dewey, 1961, p. 179).

For Al-Qabbani, on the other hand, the base of the school curriculum is satisfying the pupils' tendencies and interests, and that leads the school to be a place where the pupil lives the natural life according to his age. So the curriculum must be full of activity and experiences, and not simply an information and facts curriculum. The priority of such curriculum is devoted to playing, handicrafts, drawing, music, stories, acting, and cinema... we must aim, through its learning, to bring out the children's potentials of creativity and invention (Al-Qabbani, 1951). He believed that:

The project method of Kilpatrick is a preferred method for teaching. The first step in the project is raising the pupil's feeling that he or she needs achieve a definite goal. The next step is putting a plan to achieve this goal through the different means, and choosing a suitable one for his or her goal. The third step is implementing the plan and addressing the different problems that he or she faces using scientific facts and suitable information. The final step is validating the results and the extent to which he or she has achieved the definite goal. (Al-Qabbani, 1951, p. 64).

It seems to us that both Al-Qabbani and Dewey assured the necessity of curricula that focus on satisfying the child's tendencies and interests. They also agreed on the importance of a teaching method that gives the child a chance to learn by himself.

\section{THE APPLICATION OF DEWEY'S IDEAS IN EGYPT}

Al-Qabbani tried to apply practically the adopted ideas of Dewey. To test and develop his theoretical ideas, Dewey organized the laboratory school of the University of Chicago in 1897, which developed later into an experimental school (Benson and others, 2007). Al-Qabbani did the same in Egypt; he applied his progressive ideas by opening experimental classes in 1932. It was attached to the Institute of Education, in which teacher trainees would have the opportunity to apply what they had learned (Kombar, 2000). 
The application of Dewey's educational ideas in the practical field all over Egypt was more widely evidenced after the 1952 revolution with Al-Qabbani as a minister of education. During the first years of the revolution the concern was with consolidation of power. Pragmatic and non-ideological policies tended to be followed. The focus upon other domestic problems ensured that educational policy would not be geared toward fundamental change and would not be the object of detailed and systematic planning. In fact the changes that were made in this period essentially represented a continuous elaboration of reforms that had been previously been initiated by various governments in Egypt (Szyliowicz, 1873). A discussion of the educational fields that were most influenced by Dewey educational ideas follows.

\section{Aims of Education}

After the 1952 revolution, there was no coherent program of political, social, or economic action. Indeed, Egypt lacked the organisational and ideological infrastructure that was necessary for the successful transformation of any society. Essentially the policies that were adopted consisted of pragmatic reforms designed to deal with specific immediate problems (Szyliowicz, 1973). The Free Officers -leaders of the revolution- lacked a clear ideology after their revolution. However they put forth six targets representing their guiding principles long after the revolution. These goals included: (i) ending the British occupation and its Egyptian supporters, (ii) eliminating feudalism, (iii) ending capitalism's domination of political power, (iv) establishing social equality, (v) forming a strong popular army, and (vi) establishing true political life. These points were not included in any detailed blueprint for governing (Goldshmidt, 2004).

In light of these targets the government attempted to reconstruct the educational system in order to bring it in line with its political, social, and economic goals. Various ideas were implemented to eliminate existing blockages and to open up linkages between hitherto isolated components within the system. A stress was upon vocational, technical, and scientific training (Szyliowicz, 1973). As Minister of Education, Al-Qabbani played an important role in supporting the revolution's principles. To attain its stated aims; he drew up basic objectives for Egyptian education that included:

- Strengthening personal and social development, in conformity with each child's individual characteristics.

- Strengthening each one's mental abilities, critical thinking, deductive reasoning and creative imagination. 
- Reinforcing work skills and production experience adapted to the needs of the economy, and not limited to the sphere of government employment.

- Reinforcing the spirit of enlightened citizenship and genuine Arab nationalism (Kombar, 2000).

The outline of the progressive educational policies that the regime created after the revolution were broadly sketched in the Education Law of 1953, which brought together the primary and elementary schools, improved the transfer into secondary education, and abolished all the fees. In the early years of the revolution educational planning was initiated to define such goals as the universalisation of primary education within ten years (Williamson, 1987).

\section{Vocational Education}

It is known that Dewey emphasized the importance of vocational education, because he found it easy to manage the particular learning experience in the interest of preparing students to be social reformers (Edmondson, 2006).

After the 1952 revolution, concern was directed to vocational education. As a part of its emphasis upon scientific and practical training, the government attempted to stress technical and vocational training in order to involve the largest number of students. Hence, when the preparatory stage was created in 1953 to cover what had been the last two years of primary school and the first years of secondary school, it consisted of academic and vocational programs (Szyliowicz, 1973). In secondary education the policy was directed to the expanding of technical and agricultural education. School libraries had been enriched and teacher training was improved (Moehlman, 1963). The vocational and industrial training centres became an increasingly important part of urban life. They had counterparts in the countryside in the combined rural centres, which included health clinics, and rural craft schools (Little, 1967).

This concern for vocational education was a result of Al-Qabbani's endeavours to diversify secondary education, whereby the majority of the students would be directed into vocational schools; agricultural, industrial, or commercial. In this way, children would be guided to where their aptitudes could be developed, so as to meet the demands of development and labour markets' needs (Kombar, 2000).

\section{Teacher Preparation}

In a developing country like Egypt, at least two basic problems have to be faced: the inheritance of an education system inadequate for the country's needs, and the lack of teachers at all levels who possess the necessary qualifications to guide 
children towards an understanding and acceptance of new standards and aims (Hopwood, 1982). In 1913, the most important institution for teacher preparation in Egypt had 233 students. It did not have the capacity to meet the increasing number of applicants for admission. The building in which it was located was old, dilapidated, and constantly needed extensive and costly repairs to keep it habitable (Chirol, 1920).

Al-Qabbani was moved to action, and succeeded in convincing officials of the need to create a higher institute specializing in professional preparation for all teachers in Egyptian schools. The first institute of this kind was established in 1929 in Cairo. The institute enjoyed a good academic and educational reputation, which made it a school of pragmatism both in theory and practice, and a centre for educational research and professional training. This institute was subject to reorganization many times (Komber, 2000). Various measures were adopted to remedy its perceived deficiencies including programs to upgrade teacher quality, the introduction of new curricula, and in-service training that explains the purpose of a course, how it should be taught, and how to excite the students' interest (Szyliowicz, 1973).

This development was a result of the political and social changes after 1952 and directly resulted in a changed role of the teacher. It was necessary to prepare well-informed teachers capable of self-development and the pursuit of life-long learning, especially with the changes in educational aims, objectives related to the quantitative expansion of education, qualitative improvements in curricula and methods of teaching, and the development of suitable aids and materials for learning (Hyde, 1978).

\section{CONCLUSIONS}

The discussion of the acceptance of Dewey's educational ideas in Egypt shows that the acceptance of these ideas was in the context of the continuous movement of modernizing the Egyptian education system. Political, educational and social factors, especially during the first half of the twentieth century, had facilitated the acceptance of new and useful ideas. During these years, Egypt traversed a long road of acculturation, preserving its own cultural values and foundations and adopting modern developments in education in light of its own requirements. Emphasis was placed upon combating illiteracy and extending elementary education to the remote areas (Moehlman, 1963).

There were three stages for the acceptance of Dewey's educational ideas in Egypt. The first was the reach of these ideas; Dewey's ideas reached Egypt in three ways. The European and American schools' curriculum encouraged the adoption of western ideas. The students learned through classroom experience 
and social interaction, modern notions of class, nation, and other issues that were the focus of Dewey's writings. The educational missions to Europe and the USA included researchers and in-service teachers; the Ministry of Education sent them abroad to train in many academic and progressive educational fields. Missions were sent to the most famous universities in the United States and the United Kingdom. As a result of the continuous translation activity in Egypt, there was much scientific literature translated into the Arabic language in all fields, including education. Many books and papers by Dewey were translated and published in Arabic.

The second stage was the adoption of Dewey's ideas by many Egyptian liberal thinkers. Al-Qabbani was the most important Egyptian educationist who adopted Dewey's ideas, so their positions on some topics come close to each other, especially on the issues of aims of education, the teacher, the pupil, curriculum, and teaching method.

The third one was the application of these ideas in the practical field, especially after the 1952 revolution with Al-Qabbani as a minister of education. The application of the ideas was in light of Egypt's own educational problems and its own circumstances. The educational areas that were influenced by the progressive ideas of Dewey through Al-Qabbani included the aims of education, vocational education, and teachers' preparation. On the application side, AlQabbani also tried to apply these ideas in Egyptian education through experimental schools.

\section{References}

Ahmed, J. (1968). The intellectual origins of Egyptian nationalism. London: Oxford University Press.

Al-Qabbani, I. (1951). Studies in education's issues. Cairo: Al-Nahdah Al-Masriah.

Archambault, R. (1964). John Dewey on education: Selected writings. New York: The Modern Library.

BahaaEldin, H. (1997). Education and future. Cairo: Al-Ahram Press.

Benson, L et al (2007). Dewey's dream: Universities and democracies in an age of Education. Philadelphia: Temple University Press.

Beattie, A. (2005). Cairo: A cultural history. New York: Oxford University Press.

Botman, S. (1991). Egypt from independence to revolution 1919-1952. New York: Syracuse University Press.

Chirol, V. (1920). The Egyptian problem. London: Macmillan and Co., Limited.

Deeb, M. (1979). Party politics in Egypt: the Wafd \& its rivals 1919-1939. London: Ithaca Press.

Dunne, H. (1968). An introduction to the history of modern Egypt. London: Frank Cass.

Dewey, J. (1961). Democracy and education. New York: The Macmillan Company.

Dewey, J. (1964). What psychology can do for the teacher. In R. Archambault, John Dewey on education: Selected Writings, (pp. 195-210). New York: The Modern Library.

Dewey, J. (1964). The child and the curriculum. In R. Archambault, John Dewey on education: Selected Writings, (pp. 339-358). New York: The Modern Library.

Dewey, J. (1964). Progressive education and the science of education. In R. Archambault: John Dewey on education: Selected Writings, (PP. 169-181). New York: The Modern Library.

Edmondson, H. T. (2006). John Dewey and the Decline of American Education. USA: Wilmington, Delaware.

Egyptian Ministry of Education (1997). Education Mubarak's national project. Cairo: Book Sector.

Egyptian Ministry of Education (1998). Education Mubarak's national project. Cairo: book Sector.

El-Shibiny, M. (2008). Isma'l Al-Qabbani: 1898-1963. Available at: http://www.ttrb.ac.uk/viewarticle2. 
Faksh, M. (1980). The Consequences of the introduction and spread of modern education: Education and National Integration in Egypt. In E. Kedourie \& S. Haim, Modern Egypt: Studies in politics and society. London: Frank Cass.

Goldschmidt, A. (2004). Modern Egypt: The formation of nation state. USA: Westview Press.

Gershoni, I. \& Jankowski, J. (1995). Redefining the Egyptian nation 1930-1945. London: Cambridge University Press.

Hopwood, D. (1982). Egypt: politics and society 1945- 1981. London: George Allen \& Unwin Publishers.

Hyde, G. (1978). Education in modern Egypt: Ideals and realities. London: Routledge \& Kegan Paul.

Jankwski, J. (2002). Nasser's Egypt: Arab Nationalism and the United Arab Republic. USA: Lynne Rienner Puplisher, Inc.

Kombar, M. (1994). Isma'il Al-qabbani: 1898-1963. Prospects, Vol. XXIV, NO.1, 2, PP. 355-374.

Little, T. (1967). Modern Egypt. London: Ernest Benn Limited.

Mayer, T. (1988). The changing past: Egyptian historiography of the Urabi revolt 1882-1983. USA: University of Florida Press.

Moehlman, A. (1968). Comparative education systems. New York: The Centre for Applied Research in Education, Inc.

Rifaat, M. (1947). The Awaking of modern Egypt. London: Longman, Green and Co.

Skilbeck, M. (1970). John Dewey. London: The Malcolm Company.

Szyliowicz, J. (1973). Education and modernization in The Middle East. London: Cornell University Press.

Vatikiotis, P. (1969). The History of Egypt. London: Weidfeld and Nicolson.

Westbrook, R. (1992). John Dewey and American democracy. USA: Ithaca, New York.

Williamson, B. (1987). Education and social change in Egypt and Turkey. London: Macmillan Press.

AbdelHady EINagar is Assistant Professor in the Faculty of Education, AlAzhar University Egypt as well as an affiliate researcher and sessional instructor in the Department of Educational Administration, Faculty of Education, University of Manitoba. He can be reached at dr_elnagar@ yahoo.ca.

Eva Krugly-Smolska is an Associate Professor in the Faculty of Education at Queen's University and can be reached at kruglye@queensu.ca. 